\title{
Calcium and caffeine interaction in increased calcium balance in ovariectomized rats ${ }^{1}$
}

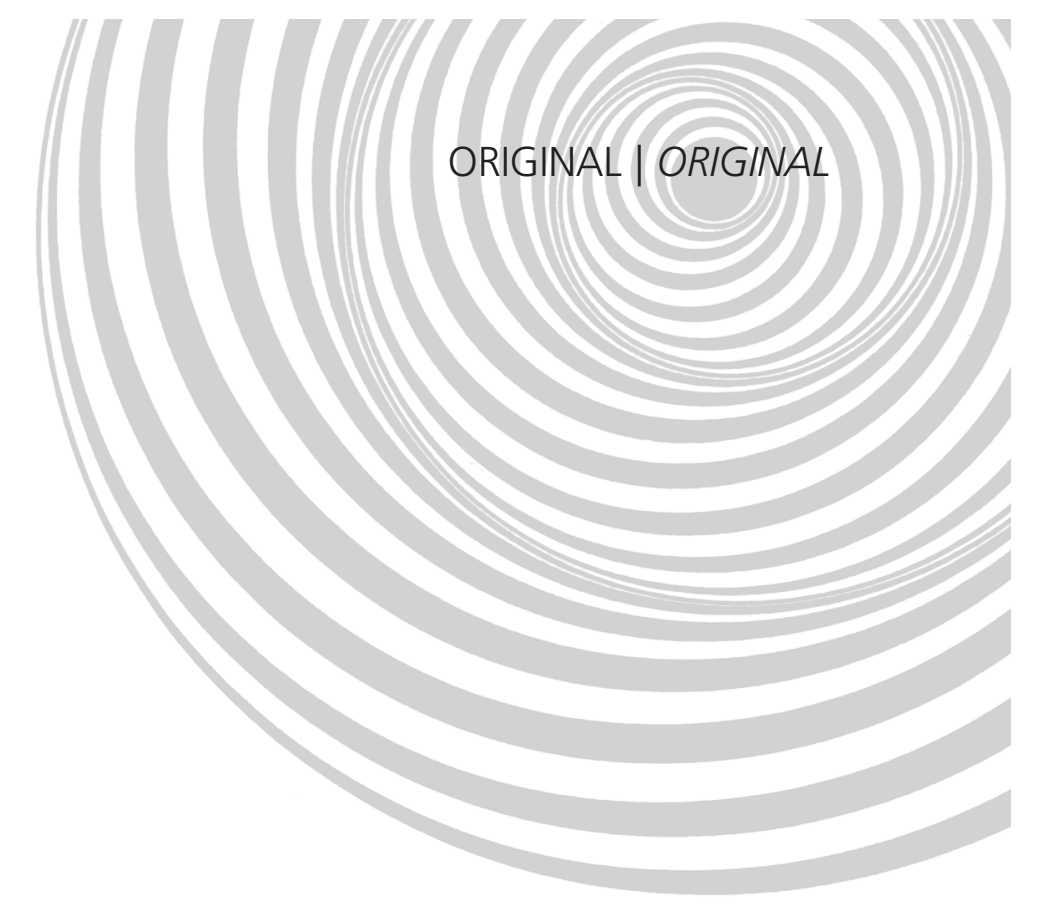

\author{
Interação cálcio e cafeina no aumento \\ do balanço de cálcio em ratas \\ ovariectomizadas
}

Sandra Tavares da SILVA

Neuza Maria Brunoro COSTA ${ }^{3}$

Frederico Souzalima Caldoncelli FRANCO ${ }^{4}$

Antônio José NATALI5

\section{A B S T R A C T}

\section{Objective}

This study investigated the effects of caffeine intake associated with inadequate or adequate calcium intake in laparotomized or ovariectomized rats by means of the calcium balance. Forty adults Wistar rats were ovariectomized or laparotomized.

\section{Methods}

The animals $(n=40)$ were randomly placed in eight groups receiving the AIN-93 diet with $100 \%$ or $50 \%$ of the recommended calcium intake with or without added caffeine $(6 \mathrm{mg} / \mathrm{kg} /$ day). The animals were kept in individuals metabolic cages at a temperature of $24^{\circ} \pm 2^{\circ} \mathrm{C}$, light/dark cycles of $12 / 12$ hours, and deionized water available ad libitum. On the $8^{\text {th }}$ week of the experiment, food consumption was measured and 24-hour urine and 4-day feces were collected to determine calcium balance [Balance=Ca intake-(Urinary Ca+Fecal Ca)].

1 Article developed as part of the dissertation data FSC FRANCO, called "Effects of ovariectomy, caffeine intake and aerobic exercise, associated to adequacy or otherwise of dietary calcium on body composition, bone tissue and calcium balance in rats". Universidade Federal de Viçosa; 2009. Sponsor: Conselho Nacional de Desenvolvimento Científico e Tecnológico and Fundação de Apoio à Pesquisa do Estado de Minas Gerais (CDS 1.562/05).

2 Universidade Federal de Viçosa, Centro de Ciências Biológicas e da Saúde, Departamento de Nutrição e Saúde. Av. P.H. Rolfs, s/n., Campus Universitário, 36570-000, Viçosa, MG, Brasil. Correspondência para/Correspondence to: ST SILVA. E-mail: <sandratavs@hotmail.com>.

3 Universidade Federal do Espírito Santo, Centro de Ciências Agrárias, Departamento de Farmácia e Nutrição. Alegre, ES, Brasil.

${ }^{4}$ Centro Federal de Educação Tecnológica de Rio Pomba, Coordenadoria Geral de Ensino, Setor de Esporte, Lazer e Artes. Rio Pomba, MG, Brasil.

5 Universidade Federal de Viçosa, Centro de Ciências Biológicas e da Saúde, Departamento de Educação Física. Viçosa, MG, Brasil. 
314 | ST SILVA et al.

\section{Results}

Animals with adequate calcium intake presented higher balances and rates of calcium absorption and retention $(p<0.05)$ than those with inadequate calcium intake, regardless of caffeine intake $(p<0.05)$. Caffeine intake did not affect urinary calcium excretion but increased balance $(p<0.05)$ in the groups with adequate calcium intake.

\section{Conclusion}

Adequate calcium intake attenuated the negative effects of estrogen deficiency and improved calcium balance even in the presence of caffeine.

Indexing terms: Caffeine. Calcium bioavailability. Estrogen.

\section{R E S U M O}

\section{Objetivo}

Investigar a relação entre a ingestão de cafeína e a adequação de cálcio dietético em ratas ovariectomizadas ou inteiras, por meio do balanço de cálcio. Foram utilizadas 40 ratas Wistar adultas submetidas à cirurgia de ovariectomia ou laparotomia.

\section{Métodos}

Os animais foram alocados em grupos $(n=5)$ e receberam dieta AIN-93M contendo 100 ou $50 \%$ da recomendação de cálcio com ou sem adição de cafeína $(6 \mathrm{mg} / \mathrm{kg} / \mathrm{dia})$. As fêmeas foram alojadas em gaiolas metabólicas individuais, à temperatura de $24 \pm 2^{\circ} \mathrm{C}$ e ciclo de 12 horas claro/escuro e receberam água deionizada ad libitum. Na oitava semana de experimento, quantificou-se a ingestão da dieta e coletaram-se fezes de 4 dias e urina dos animais por 24 horas para determinação do balanço [Balanço=Ca Ingerido - (Ca Fecal+Ca Urinário)].

\section{Resultados}

Por meio de interação entre fatores, foi observado que o consumo de $100 \%$ de cálcio elevou o balanço e os teores de cálcio absorvido e retido $(p<0,05)$ quando comparados aos grupos $50 \%$. As ratas com adequação no consumo de cálcio aumentaram o balanço $(p<0,05)$, independentemente da suplementação de cafeína. A ingestão de cafeína não afetou a excreção urinária de cálcio e elevou $(p<0,05)$ o balanço nas ratas com 100\% de cálcio, mas não nas com 50\%.

\section{Conclusão}

A adequação no consumo de cálcio atenuou os efeitos deletérios da redução estrogênica e proporcionou maior balanço de cálcio mesmo com ingestão de cafeína.

Termos de indexação: Cafeína. Biodisponibilidade do cálcio. Estrogênio.

\section{NTROD UCTION}

Osteoporosis is characterized by the World Health Organization (WHO) as a multifactorial condition $^{1-3}$ in which there is loss of bone mass and microstructural deterioration of bone tissue, increasing its fragility and, consequently, the risk of fractures ${ }^{4}$. The prevalence of osteoporosis is high, affecting about 33\% of the women aged more than 40 years $^{5}$, and because of the higher life expectancy worldwide, this figure tends to grow $^{2,6}$, since the prevalence of this disease increases with age $\mathrm{e}^{4,7}$.

The negative calcium balance observed in the osteoporosis process ${ }^{6}$ promotes bone loss, resulting in low Bone Mineral Density (BMD) which increases the risk of fractures ${ }^{2,5,7}$.

Estrogen deficiency impairs intestinal calcium absorption, possibly leading to excessive bone resorption followed by inadequate bone formation ${ }^{1,7}$. Studies show that the deleterious effects of estrogen absence are most pronounced when associated with insufficient calcium intake ${ }^{1,2}$. Velásquez-Meléndez et al. ${ }^{8}$ reported that Brazilian women ingest approximately half the recommended calcium intake, increasing the risks of osteoporosis in this group.

Dietary calcium is considered the starting point for any osteoporosis therapy or treatment. 
The impact of estrogen deficiency combined with low dietary calcium intake on calcium balance requires further investigation, especially when caffeine is also consumed.

High caffeine consumption is cited as a risk factor for osteoporosis because it increases diuresis and urinary calcium loss, reduces intestinal absorption, and inhibits bone mineralization 3,7,9,10. Studies of the interaction between caffeine and calcium on bone health are contradictory ${ }^{3,9,11-14}$. Harrys \& Dawson-Hughes ${ }^{15}$ reported that adequate calcium intake by postmenopausal women may protect them from the harmful effects of caffeine on bone metabolism. However, because calcium intake generally does not meet the recommended intake ${ }^{8}$, caffeine consumption by postmenopausal women is concerning.

Identifying factors that interfere with the rate of bone loss may help to prevent and treat osteoporosis ${ }^{7,13}$. Given the scarcity of literature reports that investigate the associated consumption of calcium and caffeine in patients with estrogen deficiency, the objective of the present study was to evaluate the effects of caffeine intake associated or not with adequate dietary calcium intake by ovariectomized or intact rats on calcium balance.

\section{METHODS}

A total of forty adult female Wistar rats (Rattus norvegicus) aged 160 days, with an average weight of $289.5 \pm 17.1 \mathrm{~g}$ (mean \pm standard deviation) were used (the groups did not differ, $p>0.05$ ). The animals were provided by the Central Animal Facility of Universidade Federal de Viçosa (UFV), Minas Gerais, Brazil, and the experimental procedures were approved by the local Research Ethics Committee on September 27, 2007 (protocol $n^{\circ}$ 80/2007). The sample size was established as recommended by Eckelman et al. ${ }^{16}$ for distinguishing the statistical differences $(p<0.05)$ between the control and treatment groups, with a coefficient of variation of $15 \%$.
Twenty animals were ovariectomized (OVX) and twenty were laparotomized (SHAM). The animals were allowed to recover in individual cages for three weeks, during which they received a commercial pelleted diet and distilled water ad libitum, the anti-inflammatory drug ketoprofen $(2 \mathrm{mg} / \mathrm{kg})$ for three days, and the antibiotic ampicillin sodium $(30 \mathrm{mg} / \mathrm{kg})$ for five days.

After the recovery period, the rats were randomly divided into eight groups $(n=5)$ in a $2 \times 2 \times 2$ factorial design, including two surgical methods (SHAM and OVX), two levels of calcium intake (50\% and $100 \%$ adequacy) and two levels of caffeine intake (with or without). Body weight and food consumption were monitored weekly.

The animals were maintained in individual stainless steel cages at an average temperature of $24^{\circ} \mathrm{C}$ and a 12 -hour photoperiod for eight weeks. They received $20 \mathrm{~g}$ of the AIN-93M semipurified diet with $50.0 \%$ (0.25\% calcium diet) or $100.0 \%$ (0.5\% calcium diet) of the recommended calcium content ${ }^{17}$ (Chart 1). The difference between the dietary calcium contents was determined by the amount of calcium carbonate (the dietary calcium source) present in the mineral mixture. Some groups also received

Chart 1. Composition of the AIN-93M diet. Viçosa (MG), Brazil, 2010.

\begin{tabular}{lc}
\hline Ingredients & Quantity in $100 \mathrm{~g}$ \\
\hline Casein (85\% protein) & 14.00 \\
Dextrinized starch (92\% tetrasaccharides) & 15.50 \\
Sucrose & 10.00 \\
Soybean oil & 4.00 \\
Fiber (microfine cellulose) & 5.00 \\
Mineral mixture* & 3.50 \\
Vitamin mixture & 1.00 \\
L-Cystine & 0.18 \\
Choline Bitartrate & 0.25 \\
Corn Starch & 46.57 \\
\hline
\end{tabular}

Note: * A mineral mixture containing $357.0 \mathrm{~g}$ of calcium carbonate per kilogram (calcium carbonate is $40.04 \%$ calcium by weight) of mineral mixture was added to the diets with $100.00 \%$ of the recommended calcium content, and half that amount $(178.5 \mathrm{~g})$ of calcium carbonate plus the same amount of sucrose was added to the diet with $50.00 \%$ of the recommended calcium content to complete the mineral mixture weight of $1 \mathrm{~kg}$. 
caffeine powder $(6 \mathrm{mg} / \mathrm{kg}$ of body weight/day) added to the diet and deionized water ad libitum. The caffeine dose was considered moderate by the authors for use in animals 18,19 .

In the eighth week of the experiment, feces and urine were collected to determine the balance (Balance=Ca intake - Fecal Ca - Urinary Ca) and the percentages of retention (\% Retention= Balance/Ca intake $\times 100$ ) and absorption (\% Absorption $=\mathrm{Ca}$ intake $-\mathrm{Fecal} \mathrm{Ca} / \mathrm{Ca}$ intake $\times 100)$ of calcium.

Calcium intake was determined by averaging four days of food intake of the animals multiplied by the calcium content of each diet $(0.5 \%$ for the diet with $100.0 \%$ calcium and $0.25 \%$ for that with $50.0 \%$ calcium).

Indigo carmine was added to the diet at a concentration of $0.2 \%$ for fecal staining. Feces were collected as follows during the days of observation: on day two, the feces stained with carmine were collected; on days three and four, all feces were collected; and on day five, only the unstained feces were collected. The fecal matter was freed from impurities by sifting. It was then weighed and oven dried at $105^{\circ} \mathrm{C}$ for 24 hours. After cooling, it was weighed and ground by a multiprocessor for further analysis of the calcium content.

Urine was collected for 24 hours after placing the animals in individual stainless steel metabolic cages. The volume was completed to $10 \mathrm{~mL}$ with deionized water and centrifuged for 15 minutes at 4,000rpm (Excelsa-Fanem, Brazil). After centrifugation, 50\% hydrochloric acid $(20 \mathrm{~mL} / \mathrm{mL})$ was added and the samples were stored in a freezer at approximately $-20^{\circ} \mathrm{C}$.

Aliquots of feces and the centrifuged urine supernatant were digested for 16-hours in concentrated nitric acid and diluted in deionized water, and the calcium content was determined by the GBC 908 AA atomic absorption spectrophotometer ${ }^{20}$. All analyses were performed in triplicate and the average calculated. The samples were prepared as recommended by the Association of Official Analytical Chemists ${ }^{21}$. The cages and glassware were demineralized with $10 \%$ nitric acid for four hours and rinsed with deionized water.

The Kolmogorov-Smirnov test was used for testing normality, and three-way analysis of variance (Anova, for the interactions and three factors) and F-tests were used for the parametric analyses. The statistical treatment was performed by the software Sigma Stat 3.0 with a significance level of $5 \%(p<0.05)$.

\section{RESULTS}

The OVX groups gained more weight than the SHAM groups $(56.4 \mathrm{~g} \pm 17.0$ versus $35.5 \mathrm{~g} \pm 11.5$, respectively) $(p<0.05)$. The SHAM and OVX groups with adequate calcium intake $(100 \%)$ presented higher $(p<0.05)$ fecal calcium content and calcium balance than those with low calcium intake (50\%) (Table 1). However, the OVX groups with adequate calcium intake exhibited lower percentages of retention and absorption

Table 1. Calcium balance for ovary and calcium interaction. Viçosa (MG), Brazil, 2010

\begin{tabular}{|c|c|c|c|c|c|c|}
\hline \multirow[b]{2}{*}{ Calcium } & \multicolumn{3}{|c|}{$100 \%$} & \multicolumn{3}{|c|}{$50 \%$} \\
\hline & $\mathrm{M}$ & & SD & $M$ & & SD \\
\hline \multicolumn{7}{|l|}{ Fecal (mg/day) } \\
\hline SHAM & 45.8 & \pm & $1.7^{\mathrm{Ba}}$ & 23.3 & \pm & $1.7^{\mathrm{Ab}}$ \\
\hline OVX & 57.5 & \pm & $1.7^{\mathrm{Aa}}$ & 25.4 & \pm & $1.7^{\mathrm{Ab}}$ \\
\hline Balance (mg/day) & & \pm & & & \pm & \\
\hline SHAM & 35.8 & \pm & $1.9^{\mathrm{Aa}}$ & 16.7 & \pm & $1.9^{\mathrm{Ab}}$ \\
\hline OVX & 23.6 & \pm & $1.9^{\mathrm{Ba}}$ & 17.4 & \pm & $1.9^{\mathrm{Ab}}$ \\
\hline$\%$ Retention & & \pm & & & \pm & \\
\hline SHAM & 43.3 & \pm & $2.5^{\mathrm{Aa}}$ & 41.5 & \pm & $2.5^{\mathrm{A}=}$ \\
\hline OVX & 28.8 & \pm & $2.5^{\mathrm{Bb}}$ & 40.1 & \pm & $2.5^{\mathrm{Aa}}$ \\
\hline$\%$ Absorption & & \pm & & & \pm & \\
\hline SHAM & 44.1 & \pm & $2.4^{\mathrm{Aa}}$ & 42.0 & \pm & $2.4^{\mathrm{Aa}}$ \\
\hline ovX & 29.2 & \pm & $2.4^{\mathrm{Bb}}$ & 40.6 & \pm & $2.4^{\mathrm{Aa}}$ \\
\hline
\end{tabular}

Note: SHAM: Laparotomized; OVX: Ovariectomized. Values in mean (M) \pm Standard Deviation (SD). Means with the same lowercase letters horizontally do not differ with respect to calcium intake (100\% or $50 \%$ ) and means with the same capital letters vertically do not differ as to the presence (SHAM) or absence (OVX) of the ovary according to the F-test $(p<0.05)$, regardless of caffeine consumption. 
than OVX groups with inadequate calcium intake; and higher fecal calcium and lower balance, \% retention, and \% absorption than the SHAM groups. The calcium balance in the SHAM and OVX groups with inadequate calcium intakes did not differ significantly.

Table 2 shows that a statistical interaction was observed in the calcium balance for the factors calcium and caffeine. All animals with adequate calcium intake, regardless of caffeine intake, presented a significantly higher calcium balance $(p<0.05)$ than those with inadequate calcium intake. All animals with adequate calcium intake consuming caffeine had a higher calcium balance than those that did not consume caffeine $(p<0.05)$.

No statistical interactions were identified ( $p>0.05$ ) between the factors in the other calcium balance parameters. The results of the calcium

Table 2. Calcium balance for calcium and caffeine. Viçosa (MG), Brazil, 2010

\begin{tabular}{|c|c|c|c|c|c|}
\hline & \multicolumn{2}{|c|}{$100 \%$} & \multicolumn{3}{|c|}{$50 \%$} \\
\hline & $\mathrm{M}$ & SD & M & & SD \\
\hline \multicolumn{6}{|c|}{ Calcium balance (mg/day) } \\
\hline No caffeine & $24.8=$ & $2.1^{\mathrm{Ba}}$ & 16.7 & \pm & 16.7 \\
\hline Caffeine & $34.6=$ & $2.1^{\mathrm{Aa}}$ & 17.4 & \pm & 17.4 \\
\hline
\end{tabular}

Note: Values in mean $(M) \pm$ Standard Deviation (SD). Means with the same lowercase letter horizontally do not differ with respect to calcium intake $(100 \%$ or $50 \%)$, and means with the same capital letters vertically do not differ with respect to caffeine intake according to the F-test $(p<0.05)$, regardless of ovariectomy status. balance for the factors ovary, calcium, and caffeine are shown in Table 3.

Considering the factor ovary, the OVX animals had higher $(p<0.05)$ fecal calcium content than the SHAM animals, although they exhibited lower urinary calcium content, balance, \% retention, and \% absorption.

The animals with adequate calcium intake had higher $(p<0.05)$ fecal and urinary calcium contents and balance, and lower levels of calcium retention and absorption than those with low calcium intake.

Animals consuming caffeine presented higher calcium balance, retention, and absorption $(p<0.05)$, and lower fecal calcium content, than those that did not consume caffeine. Caffeine did not affect urinary calcium excretion.

\section{DISCUSSION}

This study used calcium balance to investigate the effects of estrogen deficiency, inadequate dietary calcium intake, and moderate caffeine consumption on female Wistar rats. Estrogen deficiency increased body weight, reduced calcium balance, and reduced the percentage of calcium absorbed and retained. Inadequate calcium intake reduced calcium balance, but increased the percentage absorbed and retained. Moderate caffeine consumption increased calcium balance and the percentage

Table 3. Calcium balance for principal effect of the factors. Viçosa (MG) Brazil, 2010.

\begin{tabular}{|c|c|c|c|c|c|c|c|c|c|}
\hline \multirow{3}{*}{ Calcium parameters } & \multicolumn{9}{|c|}{ Principal effect of the factors } \\
\hline & \multicolumn{3}{|c|}{ Ovary } & \multicolumn{4}{|c|}{ Calcium } & \multicolumn{2}{|c|}{ Caffeine } \\
\hline & SHAM & \multicolumn{2}{|r|}{ OVX } & \multicolumn{2}{|c|}{$100 \%$} & \multicolumn{2}{|r|}{$50 \%$} & No Caffeine & Caffeine \\
\hline Ingested (mg/day) & $61.2 \pm 5.0^{\mathrm{a}}$ & 62.2 & $\pm 4.6^{\mathrm{a}}$ & 81.8 & $\pm 1.6^{\mathrm{a}}$ & 41.6 & $\pm 0.9^{\mathbf{b}}$ & $60.9 \pm 4.6^{\mathrm{a}}$ & $62.5 \pm 5.0^{\mathrm{a}}$ \\
\hline Fecal (mg/day) & $34.5 \pm 2.8^{b}$ & 41.4 & $\pm 3.9^{\mathrm{a}}$ & 51.6 & $\pm 2.0^{\mathrm{a}}$ & 24.4 & $\pm 0.7^{\mathbf{b}}$ & $39.8 \pm 3.8^{\mathrm{a}}$ & $36.2 \pm 3.0^{\mathbf{b}}$ \\
\hline Urinary (mg) & $0.42 \pm 0.06^{\mathrm{a}}$ & 0.25 & $5 \pm 0.03^{b}$ & 0.47 & $\pm 0.06^{a}$ & 0.20 & $0 \pm 0.01^{b}$ & $0.36 \pm 0.06^{\mathrm{a}}$ & $0.31 \pm 0.05^{\mathrm{a}}$ \\
\hline Balance (mg/day) & $26.3 \pm 2.5^{\mathrm{a}}$ & 20.5 & $\pm 1.6^{\mathbf{b}}$ & 29.7 & $\pm 2.2^{\mathrm{a}}$ & 17.1 & $\pm 0.8^{\mathbf{b}}$ & $20.8 \pm 1.7^{\mathbf{b}}$ & $26.0 \pm 2.5^{\mathrm{a}}$ \\
\hline$\%$ Retention & $42.4 \pm 1.5^{\mathrm{a}}$ & 34.5 & $\pm 2.3^{\mathbf{b}}$ & 36.1 & $\pm 2.4^{\mathrm{b}}$ & 40.8 & $\pm 1.6^{\mathrm{a}}$ & $35.5 \pm 2.3^{\mathbf{b}}$ & $41.4 \pm 1.7^{\mathrm{a}}$ \\
\hline$\%$ Absorption & $43.0 \pm 1.5^{\mathrm{a}}$ & 34.9 & $\pm 2.3^{b}$ & 36.6 & $\pm 2.4^{\mathrm{b}}$ & 41.3 & $\pm 1.6^{\mathrm{a}}$ & $36.0 \pm 2.3^{b}$ & $41.9 \pm 1.7^{\mathrm{a}}$ \\
\hline
\end{tabular}

Note: No caffeine. Values in mean \pm standard deviation. Means with the same lowercase letter horizontally for each variable (ovary, calcium, or caffeine) do not differ according to the F-test $(p<0.05)$. 
absorbed and retained. Finally, with respect to calcium balance, inadequate calcium intake interacted with estrogen deficiency and caffeine consumption.

Calcium intake does not mitigate the effects of ovariectomy on calcium homeostasis. The present findings corroborate those of Zhang et al. ${ }^{22}$, Kobayashi et al. ${ }^{23}$ and Mitamura et al. ${ }^{24}$. Zhang et al. ${ }^{22}$ studied OVX and SHAM SpragueDawley rats and found that OVX reduced calcium absorption and balance, resulting in increased excretion of fecal calcium. They also found that OVX animals gained more weight, a fact reported in the literature for humans and animals 22,25 attributed to hormonal disorder and greater fat accumulation. Kobayashi et al. ${ }^{23}$ reported that Fisher rats had lower calcium balance than SHAM rats due to low intestinal absorption eight weeks after ovariectomy. Mitamura et al. ${ }^{24}$ studied OVX and SHAM Sprague-Dawley rats consuming diets with different calcium contents for eight weeks and found that OVX reduced calcium balance by lowering blood estradiol levels and calcium absorption.

Hypoestrogenism reduces intestinal calcium absorption, which may stem from low enzyme activity in the intestinal mucosa, increasing fecal loss ${ }^{22}$, which supports the present results. By analogy, menopausal women with hormone deficiency and a gastrointestinal tract with naturally low absorptive capacity would be considerably susceptible to osteopenia.

Calciuria is minimized because low estrogen increases Parathormone (PTH) activity in calcium homeostasis ${ }^{2}$. This hormone maximizes calcium reabsorption in the renal tubules, so its absence may justify the high urinary calcium levels found in animals with estrogen deficiency and/ or, together with low intestinal absorption, the low levels of circulating calcium in those same animals. In contrast, estrogen receptors modulate renal tubular reabsorption of calcium and its urinary excretion, which significantly rises after menopause, suggesting lower renal reabsorption of calcium in estrogen deficiency².
Park et al. ${ }^{2}$ fed SHAM and OVX rats diets with 0.1 and $0.6 \%$ calcium contents and monitored calciuria. Excretion increased in all groups for 57 days after ovariectomy. However, from postoperative days 58 to 80 , calciuria decreased in the OVX-0.6\% calcium group. Since calciuria continued to increase in the OVX-0.1\% group, the authors inferred that adequate calcium intake enabled the rats to adapt to low estrogen. In the present study, 77 days after surgery, calciuria decreased as a function of ovariectomy and low calcium intake, but there was no interaction between the factors ovary and calcium, supporting Park et al. ${ }^{2}$. These findings are controversial, and it is not possible to confirm the mechanism of action of estrogen deficiency and inadequate calcium intake on renal calcium reabsorption.

The study groups with inadequate calcium intake lost less calcium in their feces than those with adequate intakes, regardless of OVX status. Zhang et al. ${ }^{22}$ reported similar findings and justified them by the lower amount of calcium in the intestines. Low calcium availability leads to low absorption, triggering compensatory mechanisms that are not always enough to compensate low intake. Zhang et al..$^{22}$ reported that moderate $(0.6 \%)$ and high $(1.2 \%)$ dietary calcium intakes had positive effects on the calcium balance of OVX and SHAM females. Chronic low calcium intake together with low estrogen levels may have increased the absorptive efficiency and retention in the study animals with inadequate calcium intake as a compensatory mechanism 10,22,26.

Calcium absorption is inversely proportional to consumption, particularly in times of high demand, but the total amount of calcium absorbed increases with intake ${ }^{26,27}$. This a mechanism referred to as physiological or functional adaptation to low nutrient supply. However, the minimum consumption capable of eliciting this compensatory response has not been determined because calcium absorption depends not only on its supply, but also on the presence of vitamin $D$, intestinal transit time, and calcium bioavailabiliy ${ }^{6,28}$. 
Calcium deficiency resulting from inadequate intake or low intestinal absorption may result in low levels of circulating calcium, which would increase the synthesis and release of PTH. The main action of PTH is to regulate calcium homeostasis, since its increased intestinal absorption stimulates the production of vitamin $\mathrm{D}_{3}\left(1,25(\mathrm{OH})_{2} \mathrm{D}_{3}\right)$, reduces renal excretion, and increases bone mobilization via paracrine factors, such as the receptor activator of nuclear factorkappaB ligand (RANKL), to restore optimal blood calcium levels ${ }^{4,14}$. Thus, the study animals with inadequate calcium intake may have high blood levels of PTH, which increases calcium absorption efficiency and minimizes the malabsorption promoted by ovariectomy. This may partly justify the similar calcium balance of study SHAM and OVX rats with inadequate calcium intakes.

However, the calcium balance of these animals remained lower than that of animals with adequate calcium intake. This suggests that adequate calcium intake can minimize the effects of low estrogen on calcium balance and, consequently, on bone metabolism. Estrogendeficient individuals consuming adequate amounts of calcium may have better bone health prognosis.

Type of calcium transport is another mechanism that influences absorption. Estrogen deficiency induced by ovariectomy impairs passive calcium transport ${ }^{29}$, which is primarily responsible for absorption when calcium intake is adequate or high ${ }^{27}$. However, in animals with low calcium intake, it may have increased calcium absorption by active transport in the duodenum.

Caffeine consumption has been directly related to renal calcium excretion and inversely related to intestinal absorption ${ }^{29,30}$. Daly ${ }^{29}$ and Massey \& Sutton ${ }^{30}$ suggested that cyclic adenosine monophosphate (c-AMP) acts on membrane receptors and stimulates reabsorption of calcium in renal tubules, potentially blocked by caffeine intake, increasing renal excretion and leading to hypercalciuria. In an epidemiological study of middle-aged women, Heaney ${ }^{31}$ found that caffeine intake did not change calcium balance and absorption. However, a negative correlation was identified between caffeine intake and calcium balance.

Contrary to literature reports, the present study found that caffeine intake increased calcium balance and percentages of absorption and retention, and reduced fecal losses, while urinary losses remained stable. Alternatively, Zhou et al..$^{14}$ suggested that, by inhibiting c-AMP degradation, caffeine may increase its levels and promote the release of PTH, which regulates serum calcium homeostasis. Therefore, PTH could increase intestinal absorption and bone mobilization and reduce renal calcium excretion ${ }^{4,14}$. In this study, low fecal calcium and high calcium balance promoted by caffeine may be associated with an increase in c-AMP induced by caffeine, increasing the release of PTH and thereby increasing intestinal absorption. The increase in serum calcium levels could subsequently decrease secretion of PTH, preventing hypercalcemia and bone resorption?

Nonetheless, Chen \& Whitford ${ }^{32}$ reported that high caffeine intake ( 25 and $100 \mathrm{mg} / \mathrm{kg} /$ day) by six-week-old Sprague-Dawley rats did not change calcium balance, absorption, or fecal content. These controversial findings suggest the need of studies that investigate the possible mechanisms of action of caffeine on calcium homeostasis.

In the current study, rats with adequate calcium intake had higher balance, regardless of caffeine supplementation. However, caffeine ingestion only increased calcium balance in rats with adequate intake. The absence of caffeine action on the balance of the groups with inadequate calcium intake can be explained by the better calcium absorptive efficiency promoted by a compensatory mechanism, as suggested previously ${ }^{26}$. However, the calcium balance in animals with inadequate calcium intake was approximately half that of animals with adequate calcium intake, which would make them more 
susceptible to metabolic disorders caused by negative calcium balance. These data stress the impact of calcium ingestion on its balance.

Rapuri et al. ${ }^{3}$ states that the main interference factor on bone metabolism is calcium intake adequacy, which directly affects its balance. However, studies on women of all ages have shown that calcium intake does not correlate with $\mathrm{BMD}^{13}$ and bone turnover markers ${ }^{12}$. On the other hand, calcium balance can be influenced by other factors, such as estrogen deficiency and caffeine consumption 6,12,30.

Studies show an inverse relationship between caffeine and calcium intakes: high caffeine intake is found in individuals with low calcium intake ${ }^{3,6,10}$. Wetmore et al. ${ }^{10}$ studied 625 Americans and found a higher caffeine intake (>200mg/day) in women with calcium intakes below $800 \mathrm{mg} /$ day. The consumption of three daily cups of coffee daily (approximately $180 \mathrm{~mL}$ ), corresponding to $300 \mathrm{mg}$ of caffeine, was associated with BMD loss in older women who do not consume milk and dairy products regularly ${ }^{3}$. It has been suggested that high caffeine intake has a modest effect on calcium loss in most people $^{3}$, and the deleterious effects of this compound may be nullified by adequate calcium intake ${ }^{11}$. However, more studies are needed to clarify the interaction between calcium and caffeine on calcium balance.

Caffeine/coffee intake increases urinary calcium excretion ${ }^{29-31}$ and reduces calcium balance ${ }^{31}$, BMD $^{11}$, and bone formation ${ }^{31}$. However, in the present study, caffeine tended to reduce urinary calcium excretion, confirming the mechanism by which caffeine increases cAMP, which stimulates the release of PTH, which in turn inhibits renal calcium excretion ${ }^{14}$.

Zhou et al. ${ }^{14}$ showed that caffeine exerts negative effects on bone metabolism only when estrogen is low or absent, and attributed the calcium loss promoted by caffeine to the antagonistic role of this hormone. Although estrogen deficiency led to lower calcium balance in the study groups, there was no significant interaction between caffeine intake and estrogen deficiency on calcium balance. The present results confirm that caffeine intake did not affect calcium balance and hence did not harm BMD and bone turnover markers ${ }^{12,13}$.

Therefore, calcium balance alone may not express the effects of caffeine on bone metabolism, at least in the subclinical stage. Regular caffeine intake may not impact the apparent ability of the body to adapt to inadequate calcium intake and estrogen deficiency in ways that are not yet understood. Moreover, existing damage to the bone microstructure along with chronic exposure to caffeine alone or in combination with other factors may increase the risk of fractures.

\section{CONCLUSION}

Adequate calcium intake mitigated the deleterious effects of estrogen deficiency and caffeine consumption. Inadequate calcium intake improved absorptive efficiency but not balance. In contrast to previous publications, caffeine increased calcium balance and reduced fecal calcium losses. Thus, adequate calcium intake is important for proper calcium homeostasis and for reducing the risk of osteoporosis, especially in caffeine consumers. Studies in postmenopausal women using markers of bone remodeling, densitometry, or isotopic techniques are needed to better elucidate the mechanisms of action of caffeine associated with dietary calcium intake.

\section{ONTRIBUTORS}

ST SILVA participated in the study design, execution, and writing. NMB COSTA contributed to the study conception, design, writing, and review. FSC FRANCO participated in the study conception, design, execution, writing, and review. AJ NATALI contributed to the study conception, design and review. 


\section{REFEREN CES}

1. Jasminka ZI, Brownbill RA, Tamborini L, CrncevicOrlic Z. To drink or not to drink: How are alcohol, caffeine and past smoking related to bone mineral density in elderly women? J Am Coll Nutr. 2002; 21(6):536-44.

2. Park JH, Omi N, Nosaka T, Kitajima A, Ezawa I. Estrogen deficiency and low-calcium diet increased bone loss and urinary calcium excretion but did not alter arterial stiffness in young female rats. J Bone Miner Metab. 2008; 26(3):218-25. doi: 10.1007/s0 0774-007-0822-4.

3. Rapuri PB, Gallagher JC, Kinyamu HK, Ryschon KL. Caffeine intake increases the rate of bone loss in elderly women and interacts with vitamin D receptor genotypes. Am J Clin Nutr. 2001; 74(5): 694-700.

4. Institute of Medicine. Dietary Reference Intakes: Calcium, phosphorus, magnesium, vitamin D and Fluoride. Washington (DC): The National Academic Press; 1998.

5. Pinheiro MM, Neto ETR, Machado FS, Omura F, Yang JHK, Szejnfeld J, et al. Risk factors for osteoporotic fractures and low bone density in pre and postmenopausal women. Rev Saúde Pública. 2010; 44(3):479-85. doi: 10.1590/S0034-891020 10000300011.

6. Lanzillotti HS, Lanzillotti RS, Trotte APR, Dias AS, Bornand B, Costa EAMM. Osteoporosis in postmenopausal women, dietary calcium and other risk factors. Rev Nutr. 2003; 16(2):181-93. doi: 10.1590/S1415-52732003000200005.

7. Clarke BL, Khosla S. Physiology of bone loss. Radiol Clin North Am. 2010; 48(3):483-95. doi: 10.1016/ j.rcl.2010.02.014.

8. Velásquez-Meléndez G, Martins IS, Cervato AM, Fornés NS, Marucci MFN. Consumo alimentar de vitaminas e minerais em adultos residentes em área metropolitana de São Paulo, Brasil. Rev Saúde Pública. 1997; 31(2):157-62. doi: 10.1590/S0034-89 101997000200009.

9. Altimari LR, Moraes AC, Tirapegui J, Moreau RLM. Cafeína e performance em exercícios anaeróbios. Braz J Pharm Sci. 2006; 42(1):17-27. doi: 10.1590/ S1516-93322006000100003.

10. Wetmore CM, Ichikawa L, LaCroix AZ, Ott SM, Scholes $D$. Association between caffeine intake and bone mass among young women: Potential effect modification by depot medroxyprogesterone acetate use. Osteoporos Int. 2008; 19(4):519-27. doi: 10.1007/s00198-007-0473-2.

11. Franco FSC. Efeitos da suplementação de creatina associada ou não à cafeína em ratos submetidos a exercício anaeróbico intermitente [mestrado]. Viçosa: Universidade Federal de Viçosa; 2004.

12. Ardawi MS, Maimani AA, Bahksh TA, Rouzi AA, Qari $\mathrm{MH}$, Raddadi RM. Reference intervals of biochemical bone turnover markers for Saudi Arabian women: A cross-sectional study. Bone. 2010; 47(4):804-14. doi: 10.1016/j.bone.2010.0 7.017.

13. Conlisk AJ, Galuska DA. Is caffeine associated with bone mineral density in young adult women? Prev Med. 2000; 31(5):562-8. doi: 10.1006/pmed.200 0.0742

14. Zhou Y, Zhu ZL, Guan XX, Hou WW, Yu HY. Reciprocal roles between caffeine and estrogen on bone via differently regulating CAMP/PKA pathway: The possible mechanism for caffeine-induced osteoporosis in women and estrogen's antagonistic effects. Med Hypotheses. 2009; 73(1):83-5. doi: 10.1016/j.mehy.2009.01.029.

15. Harris SS, Dawson-Hughes B. Caffeine and bone loss in healthy postmenopausal women. Am J Clin Nutr. 1994; 60(4):573-8.

16. Eckelman WC, Kilboum MR, Joyal JL, Labiris $R$, Valliant JF. Justifying the number for each experiment. Nucl Med Biol. 2007; 34(3):229-32. doi:10.1016/j.nucmedbio.2007.01.005.

17. Reeves PG, Nielsen FH, Fahey GC, Jr. AIN-93 purified diets for laboratory rodents: Final report of the American Institute of Nutrition ad hoc writing committee on the reformulation of the AIN-76A rodent diet. J Nutr. 1993; 123(11):1939-51.

18. Doherty M, Smith P, Hughes M, Davison R. Caffeine lowers perceptual response and increases power output during high-intensity cycling. J Sports Sci. 2004; 22(7):637-43. doi: 10.1080/02640410310 001655741.

19. O'Connor PJ, Motl RW, Broglio SP, Ely MR. Dosedependent effect of caffeine on reducing leg muscle pain during cycling exercise is unrelated to systolic blood pressure. Pain. 2004; 109(3):291-8. doi: 10.1016/j.pain.2004.01.017

20. Silva JD. Análise de alimentos: métodos químicos e biológicos. Viçosa: Imprensa Universitária; 1990.

21. Association of Official Analytical Chemists. Official methods of analysis. Washington (DC): AOAC; 1998.

22. Zhang $Y$, Dong $X L$, Leung $P C$, Che $C T$, Wong $M S$. Fructus ligustri lucidi extract improves calcium balance and modulates the calciotropic hormone level and vitamin D-dependent gene expression in aged ovariectomized rats. Menopause. 2008; 15(3): 558-65. doi: 10.1097/gme.0b013e31814fad27.

23. Kobayashi M, Hara K, Akiyama Y. Effects of vitamin K2 (menatetrenone) on calcium balance in 
ovariectomized rats. Jpn J Pharmacol. 2002; 88(1): 55-61.

24. Mitamura R, Hara H, Aoyama Y, Chiji H. Supplemental feeding of difructose anhydride III restores calcium absorption impaired by ovariectomy in rats. J Nutr. 2002; 132(11):3387-93.

25. Shinoda M, Latour MG, Lavoie JM. Effects of physical training on body composition and organ weights in ovariectomized and hyperestrogenic rats. Int J Obesity Relat Metab Disord. 2002; 26(3):335-43. doi: 10.1038/sj/ijo/0801900.

26. Iwamoto J, Yeh JK, Takeda T, Sato Y. Effects of vitamin $D$ supplementation on calcium balance and bone growth in young rats fed normal or low calcium diet. Horm Res. 2004; 61(6):293-9. doi: 10.1159/000077346.

27. Lobo AR. Efeito dos frutanos (frutooligossacarídeos) na biodisponibilidade de cálcio e magnésio em ratos [mestrado]. São Paulo: USP; 2004.

28. Silva CC, Teixeira AS, Goldberg TBL. Impacto da ingestão de cálcio sobre a mineralização óssea em adolescentes. Rev Nutr. 2004; 17(3):351-9. doi: 10.1 590/S1415-52732004000300008.

29. Daly JW. Caffeine analogs: Biomedical impact. Cell Mol Life Sci. 2007; 64(16):2153-69. doi: 10.1007/s0 0018-007-7051-9.

30. Massey LK, Sutton RA. Acute caffeine effects on urine composition and calcium kidney stone risk in calcium stone formers. J Urol. 2004; 172(2):555-8. doi: 10.1097/01.ju.0000129413.87024.5c.

31. Heaney RP. Effects of caffeine on bone and the calcium economy. Food Chem Toxicol. 2002; 40(9): 1263-70. doi: 10.1016/S0278-6915(02)00094-7.

32. Chen X, Whitford GM. Effects of caffeine on fluoride, calcium and phosphorus metabolism and calcified tissues in the rat. Arch Oral Biol. 1999; 44(1):33-9. doi: 10.1016/S0278-6915(02)00094-7.

Received on: 12/7/2012

Final version on: 27/11/2012

Approved on: 5/2/2013 